RESEARCH ARTICLE - TERMITES

\title{
Global Elevational, Latitudinal, and Climatic Limits for Termites and the Redescription of Rugitermes laticollis Snyder (Isoptera: Kalotermitidae) from the Andean Highlands
} \author{
RJ HIGGINS ${ }^{7}$, BS LINDGREN ${ }^{8}$, R CONSTANTINO $^{9}$, S ISSA $^{10}$, AND E KUSWANTO ${ }^{11}$ \\ 1 - Fort Lauderdale Research \& Education Center, Davie, Florida, USA \\ 2 - Terminix International, Memphis, Tennessee, USA \\ 3 - City of Guelph, Building Services, Ontario, Canada \\ 4 - BASF Corporation, North Carolina, USA \\ 5 - Integrated DNA Technologies, Inc., 1710 lowa, EUA \\ 6 - Royal British Columbian Museum, Victoria BC, Canada \\ 7 - Department of Biological Sciences, Thompson Rivers University, British Columbia, Canada \\ 8 - University of Northern British Columbia, British Columbia, Canada \\ 9 - Universidade de Brasília, Brasília, DF, Brazil \\ 10 - Universidad Simón Bolívar, Caracas, Venezuela \\ 11 - School of Life Sciences and Technology, Bandung Institute of Technology, Ganesa, Indonesia
}

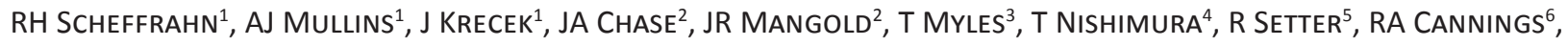

\section{Article History}

Edited by

Gilberto M. M. Santos, UEFS, Brazil

Received 14 April 2015

Initial acceptance 18 June 2015

Final acceptance 11 August 2015

\section{Keywords}

Termites, Andean Highlands, Rugitermes

Laticollis Snyder, Redescription.

\section{Corresponding author}

Rudolf H Scheffrahn

Fort Lauderdale Research \&

Education Center

3205 College Avenue, Davie

33314, Florida, USA

E-Mail: rhsc@ufl.edu

\begin{abstract}
We compile, map, and discuss global elevational, latitudinal, thermal, and rainfall extremes of termite localities from literature sources and unpublished records. Rugitermes laticollis from Ecuador and Bolivia occurs at higher elevation (2700-3600 m) than any other termite species. Termites span the globe from $54.3^{\circ} \mathrm{N}$ (Zootermopsis angusticollis in British Columbia (B.C.), Canada) to $48.9^{\circ} \mathrm{S}$ (Porotermes quadricollis in Magdalena, Chile). The coldest locality supporting termites (Reticulitermes sp.) is at Churn Creek, B.C., where the mean annual temperature is $4^{\circ} \mathrm{C}$. Lake Havasu City, Arizona, where Heterotermes aureus and Gnathamitermes perplexus occur, has the highest recorded temperature maximum $\left(52^{\circ} \mathrm{C}\right)$ for a termite locality. Cryptotermes brevis and Neotermes chilensis are endemic to the Pacific Coast of Peru and Chile where rain is essentially absent. We further provide locality extremes for six termite families from six zoogeographical regions. In addition, the winged imago of Ru. laticollis is redescribed and the soldier is described for the first time.
\end{abstract}

\section{Introduction}

Taxonomic diversity declines for most organisms as climatic temperatures decrease either from increasing elevation (Rahbek, 1995) or increasing latitude (Willig et al., 2003; Mittelbach et al., 2007). Termites also show reduced diversityas elevation increases above ca. $800 \mathrm{~m}$ (Inoue et al., 2006; Palin et al., 2011; Gathorne-Hardy et al., 2001) and as latitude becomes extra-tropical (Emerson, 1952; Cancello et al., 2014). Termite diversity is overwhelmingly greatest in the tropics $\left(\leq 23.5^{\circ} \mathrm{N}\right.$ and $\left.\mathrm{S}\right)$ where several hundred genera are recorded compared to five found in the temperate regions $\left(\geq 40^{\circ} \mathrm{N}\right.$ and $\mathrm{S}$, Jones \& Eggleton, 2011). In addition to elevational and latitudinal extremes, some termite species also occupy environments in hot or arid deserts and in nearfreezing climates (Emerson, 1936; Emerson, 1955).

Among T.E. Snyder's last taxonomic publications was a note on a new termite from Bolivia (Snyder, 1957). Therein, he briefly describes winged adults of Rugitermes laticollis from a sample which he "found" in the Smithsonian collection where he worked. What is especially noteworthy was Snyder's account of the type locality of his new species as 
follows: "La Paz, Bolivia. Described from 6 winged adults, 4 males and 2 females, collected at the type locality by R. Pérez Alcalá, 1947."

Unaware of $R u$. laticollis, one of the authors (AJM) traveled to Quito, Ecuador, after departing from a 2010 termite expedition to the Ecuadorian Amazon. After reuniting, AJM reported finding a kalotermitid species in a tree at a city park in Quito. Having found very few termites in the neotropics above $1600 \mathrm{~m}$, we were astonished to learn of AJM's find at an elevation of $2800 \mathrm{~m}$ ! On our return, we determined that the Quito sample was indeed Ru. laticollis Snyder. We now surmise that Snyder (1957) did not realize the altitudinal significance of the La Paz locality for $R u$. laticollis which is even more elevated than Quito by some 400 to $1400 \mathrm{~m}$. Furthermore, after reviewing the UF collection holdings, a third high-elevation sample of $R u$. laticollis was identified from Luribay, Bolivia (2700 m).

Prompted by our unexpected collection of $R u$. laticollis and the lack of a compilation of termite localities at the limits of termite habitation, we herein review published records and provide new data on the elevational, latitudinal, thermal, and rain fall limits of representative termite taxa worldwide. Furthermore, we describe for the first time, the soldier of $R u$. laticollis and redescribe its winged imagos.

\section{Materials and Methods}

Elevation and locality coordinates (Appendix) were taken from published data or from our database (University of Florida (UF) Termite Collection, Davie, Florida) listed as "current paper" in Appendix. Most specimens in the UF collection were taken during week-long expeditions in which the goal was to acquire maximum regional diversity. In some cases, published elevation, geographic coordinates, and locality names were confirmed or corrected using Google Earth and web resources. Climatic data were taken from http://www.weatherbase.com/.

Rugitermes laticollis localities and those reported or selected for other termite taxa were mapped (Fig 1) using ArcGIS Desktop 10.2 software. Figures 2 and 3 were taken as multilayer montages using a Leica M205C stereomicroscope

Table 1. Measurements of Rugitermes laticollis winged imagos $(\mathrm{n}=7)$.

\begin{tabular}{|c|c|c|c|c|}
\hline & \multicolumn{2}{|c|}{ females $(n=3)$} & \multicolumn{2}{|c|}{ males $(n=4)$} \\
\hline & mean & range & mean & range \\
\hline $\begin{array}{l}\text { Head width max. } \\
\text { (without eyes) }\end{array}$ & 1.73 & $1.50-2.00$ & 1.64 & $1.60-1.75$ \\
\hline Pronotum width & 1.96 & $1.88-2.06$ & 2.02 & $1.83-2.13$ \\
\hline Eye diam. max & 0.37 & $0.36-0.38$ & 0.38 & $0.37-0.39$ \\
\hline Body length & 8.89 & $8.66-9.00$ & 8.93 & $8.75-9.10$ \\
\hline $\begin{array}{l}\text { Right forewing } \\
\text { length }\end{array}$ & 9.35 & $9.05-9.75$ & 9.54 & $9.25-9.90$ \\
\hline $\begin{array}{l}\text { Body length with } \\
\text { wings }\end{array}$ & 11.77 & $11.30-12.25$ & 12.20 & $12.00-12.65$ \\
\hline
\end{tabular}

controlled by Leica Application Suite version 3 software. Montage specimens were taken from $85 \%$ ethanol and positioned in Purell ${ }^{\circledR}$ Hand Sanitizer contained within a transparent plastic Petri dish bottom. Field photographs of $R u$. laticollis (Figs 4 and 5) were taken with a Nikon 7SC digital camera in macro flash (Fig 4) or non-macro (Fig 5) mode. Measurements (Tables 1 and 2) were taken with an Olympus SZH stereomicroscope with an ocular micrometer.

\section{Results}

\section{Elevational Maxima}

In most of the world's tropics, termite diversity and abundance are greatest from sea level to about $1200 \mathrm{~m}$ (Inoue et al., 2006). Palin et al. (2011) reported a decrease in termite diversity and abundance with increased elevation in Peru and found no termites above $1550 \mathrm{~m}$. Atkin and Proctor (1988) found no termites at $1500 \mathrm{~m}$ or above on a Costa Rican volcano. On Mount Giting-Giting, Philippines, Thomas and Proctor (1997) found a few termite species at $1240 \mathrm{~m}$ elevation and none at $1540 \mathrm{~m}$. Collins (1980) reported the upper limit of termites at $1850 \mathrm{~m}$ on the West Ridge of Gunung (Mount) Mulu, Sarawak. Gathorne Hardy et al. (2001) found the least termite diversity (five species) at $1400 \mathrm{~m}$ compared to 11-35 species at lower elevations on the island of Sumatra. In our New World sampling efforts, Scheffrahn et al. (unpublished data) have observed a similar elevational decline in termite diversity. The Appendix provides a summary of 33 reported and 24 new global elevational maxima for selected termite taxa.

The most elevated locality reported for any termite is 3900 $\mathrm{m}$ for "Kunwari Pass", Chamoli State, India, for the damp wood termite, Archotermopsis wroughtoni (Roonwal et al., 1984). This elevation is $1100 \mathrm{~m}$ higher than the next highest of the 35 localities reported by these authors. The name and elevation of this western Himalayan site, however, could not be confirmed on Google Earth, the Web, or maps of northern India. When queried for "Kunwari Pass", internet resources only yielded the town of Joshimath $(1860 \mathrm{~m})$ which is at the trail head of "Kauri Pass". Shedding further doubt on the "Kunwari Pass" locality, Imms (1920) is quoted: "In June, 1910, I first came across this insect in a decaying fallen trunk of Pinus excelsa, in a forest area situated between the Kuari Pass and Ramni, at an altitude of about 8,500 feet, in the Himalayas of British Garwhal." Imms (1920) further

Table 2. Measurements of Rugitermes laticollis soldiers $(\mathrm{n}=10)$.

\begin{tabular}{lll}
\hline & mean & range \\
\hline Head length to lateral mandible base & 3.08 & $2.50-3.33$ \\
Head widthmax. & 2.06 & $1.83-2.43$ \\
Head height with gula max. & 1.64 & $1.40-1.83$ \\
Pronotum length & 1.08 & $1.00-1.17$ \\
Pronotum width & 2.21 & $1.93-2.76$ \\
No. antennal articles & 15 & $14-16$ \\
\hline
\end{tabular}




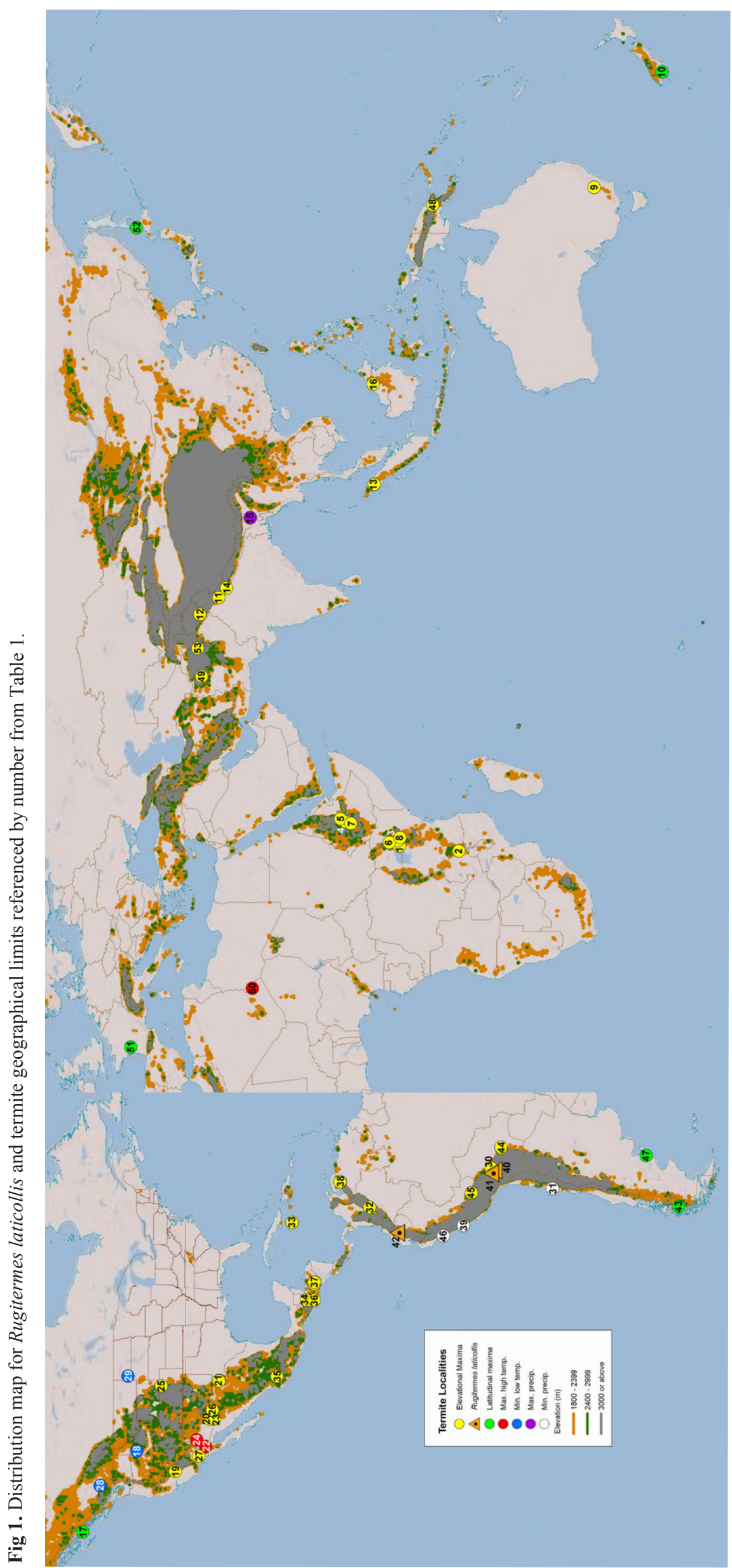


notes that N.C. Chatterjee provided him with material taken at $2743 \mathrm{~m}$ in Deoban, Uttar Pradesh. Deoban, is the second highest Ar. wroughtoni site listed at $2800 \mathrm{~m}$ by Roonwal et al. (1984) and is very likely the same sample referenced by Imms (1920). Google Earth gives the elevation of Deoban village at over 400 $\mathrm{m}$ lower $(2280 \mathrm{~m})$. This leaves the highest confirmed locality of material examined by Roonwal et al. (1984) as Gulmarg, Jammu and Kashmir Province (2700 m). Although the exact locality in La Paz from which Snyder's (1957) original $R u$. laticollis sample was collected cannot be determined, the elevational range for this city is between 3400-4000 m (http:// travel.state.gov/travel/ cis_pa_tw/cis/cis_1069.html) with the old central plaza at $3600 \mathrm{~m}$. The recorded elevational mean and range for $\mathrm{Ru}$. laticollis iscurrently more elevated and narrower $(2700-3600 \mathrm{~m})$ than that of Ar. wroughtoni (1000-2743 m, Roonwal et al., 1984).

Elevational records for the Afrotropics are limited to the higher termites (family Termitidae) which reach a maximum elevation in the highlands surrounding the Great Rift Valley of Ethiopia and Kenya. Here, all Afrotropical subfamilies except Nasutitermitinae have been recorded at $1900 \mathrm{~m}$ or above (Appendix). The epigeal mounds of Cubitermes and Odontotermes colonies are conspicuous in these more barren highlands. In Ethiopia, Cowie et al. (1990) reported that "above $2000 \mathrm{~m}$ the fauna is very restricted, but Odontotermesis found in Addis Ababa (ca. $2300 \mathrm{~m}$ ) and a single worker of a completely subterranean Odontotermes species was seen (but not collected) near Debre Birhan at about 3200m". Google Earth, however, gives the elevation of the Debre Birhan plateau at $2800 \mathrm{~m}$. Sjöstedt's 1905 record of Odontotermes apollo at $2600 \mathrm{~m}$ from Eburru, Kenya, is the elevational maximum for the family Termitidae. Donovan et al. (2002) collected 11 genera of Termitidae, many of which are soldierless soil feeders in the subfamily Apicotermitinae, at $1900 \mathrm{~m}$ on the Nyika Plateau of Malawi. The nasutitermitine genus Trinervitermes, although reported to be very rare in the area, was recorded at $1650 \mathrm{~m}$ at Adami Tullu, Ethiopia (Debelo \& Degaga, 2014).

The only significant elevational records for the Australian Region include the Family Stolotermitidae (Porotermes adamsoni and Stolotermes vitoriensis) from the Brindabella Range near Canbarra (1300 m, Lacey et al., 2010). The highest report for termites in Papua New Guinea is that of Pericapritermes cf. schultzei collected in the Bismarck Range at $1650 \mathrm{~m}$ (Bourguignon et al., 2008). In addition to the elevation records for Ar. wroughtoni noted above, the Himalayan foothills also support Odontotermes distans at 2250m (Thakur, 1981). Elevational records in the eastern Indomalayan region include two nasutermitine genera, Bulbitermes and Longipeditermes, from Sumatra (1400 m) and Bulbitermes from Malaysia (1860 m, Appendix).

Since 2004, the neotropical mainland has been the subject of largely unpublished termite biodiversity surveys ( $c f$. UF Collection) with the Kalotermitidae generally occupying higher elevations than other families of the region (Appendix). Aside from Ru. laticollis and the exotic Cryptotermes brevis, members of the kalotermitid genera Comatermes, Glyptotermes, Incisitermes, Marginitermes, and Neotermes have been recorded above $1500 \mathrm{~m}$ in the highlands of Guatemala and Honduras (Appendix). A new species of Neotermes was collected at 1831 $\mathrm{m}$ from a damp log in Parque Nacional de Yacumba, Venezuela. Coptotermes testaceus and Heterotermes convexinotatus (Rhinotermitidae) have also been found at elevations above $1500 \mathrm{~m}$ in the Central American highlands. In South America, mostly Termitidae have been recorded above $1400 \mathrm{~m}$ including Anoplotermes turricola and Procornitermes lespesii (Bolivia) and Nasutitermes guayanae and Na. octopilus (Peru, Palin et al., 2011). The highest elevation for termites in the West Indies is currently at $1239 \mathrm{~m}$ for Glyptotermes liberatus in the Blue Mountains of eastern Jamaica. We expect, however, that the West Indian elevational record actually lies in the poorly accessible Cordillera Central of the Dominican Republic which rises to Pico Duarte at $3098 \mathrm{~m}$.

In the Nearctic Region, only Reticulitermes sp. (Rhinotermitidae) and Zootermopsis sp. (Archotermopsidae) have been found above $2000 \mathrm{~m}$ (Appendix). A colony of the western drywood termite, Incisitermes minor, was sampled from a pine $\log$ in the Davis Mountains of Texas at an elevation of 1772 m. Gnathamitermes nr. perplexus and Amitermesnr californicus [not a synonym of Am. wheeleri (Desneux) Scheffrahn unpubl. obs.] were collected near I. minor at slightly lower elevation. Tenuirostritermes tenuirostris, the only nasutitermitine of the Nearctic, was collected at $1765 \mathrm{~m}$ in the Chiricahua Mountains of southeastern Arizona. Winter snowfall accumulations are common in these mountains. In the Palearctic, both elevational records are from Afghanistan. Anacanthotermes septentrionalis is reported at $2000 \mathrm{~m}$ in Jija, a record for the family Hodotermitidae. Microcerotermes gabrielis was collected at $1850 \mathrm{~m}$ in Kabul (Weidner, 1960).

It should be mentioned that two termite species have been found along the Red Sea where elevation below sea level is a global minimum. Angulitermes quadriceps was collected around Jericho and Sdom, Israel, at about $-252 \mathrm{~m}$ (Harris, 1964), and Microcerotermes palestinensis was found in Ein Gedi, Israel, at about -282 m (Spaeth, 1964).

\section{Latitudinal Maxima}

The northern global limits of termite distribution are reported by Vickery and Kevan (1985) who recorded Zootermopsis angusticollis at $54.3^{\circ} \mathrm{N}$ (Prince Rupert, British Columbia) and Z. nevadensis at $53.3^{\circ} \mathrm{N}$ (Dunkley, BC, near Quesnel). Coastal southern Alaska needs to be surveyed for the possibility of a more northerly record for Zootermopsis sp. (R.A. Cannings pers. comm.). A Reticulitermes sp. was collected as far north inland as $51.3^{\circ} \mathrm{N}$ (Churn Creek Protected Area near Dog Creek, BC; coll. RJH) and near Kamloops, British Columbia (50.7 N, Vickery \& Kevan, 1985;).The 
southern limits for termites are ca. $48.9^{\circ} \mathrm{S}$ for Porotermes quadricollis (Magallanes Province, Chile, Constantino, 1998) followed by Stolotermes ruficeps at ca. $46^{\circ} \mathrm{S}$ ("widespread throughout New Zealand", Bain \& Jenkin 1983). For a higher termite, Onkotermes brevicorniger holds the record at $43.3^{\circ} \mathrm{S}$ (Rawson, Chubut Province, Argentina, Constantino et al., 2002).

\section{Precipitational and Thermal Extremes}

The Pacific coast of Peru and northern Chile receives the least rainfall of any nonpolar region on earth. However, due to riparian habitats nurtured by Andean snowmelt, both the Peruvian and the Atacama deserts support woody growth and termites. This remarkably cool and humid desert coastline is the endemic habitat of Cryptotermes brevis (Scheffrahn et al., 2009) and Neotermes chilensis, the latter occurring in both dead wood and inside living trees (Scheffrahn pers. obs.).Amitermes lunae was discovered in soil at a Moche archeological site near Trujillo, Peru (Scheffrahn \& Huchet, 2010) which receives a mere $0.5 \mathrm{~cm}$ of rainfall annually. Termites are common to very wet circum-tropical climates. The village of Cherrapunji at the base of the Himalayas in Assam Province, India, receives more rain, at $10.6 \mathrm{~m}$ per annum, than any place on earth. Roonwal and Chhotani (1962) report four termitid genera from Cherrapunji (Appendix).

The termite localities with the highest recorded temperature maxima include Lake Havasu City, Arizona $\left(52^{\circ} \mathrm{C}\right.$, Heterotermes aureus and Gnathamitermes perplexus $)$, Imperial California $\left(51^{\circ} \mathrm{C}\right.$, Marginitermes hubbardi), and Ghat, Libya $\left(51^{\circ} \mathrm{C}\right.$, Psammotermes hybostoma, Harris, 1966$)$. The coldest annual mean (record minima) where termites occur include Churn Creek, B.C. $4^{\circ} \mathrm{C}\left(-40^{\circ} \mathrm{C}\right)$ for Reticulitermes sp.; New Meadows, Idaho, $5^{\circ} \mathrm{C}\left(-45^{\circ} \mathrm{C}\right)$ for $Z$. angusticollis; Dunkley, B.C. $5.5^{\circ} \mathrm{C}\left(-47^{\circ} \mathrm{C}\right)$ for Z. nevadensis; and Amidon, North Dakota, $6^{\circ} \mathrm{C}\left(-40^{\circ} \mathrm{C}\right)$, for $R$. tibialis (Emerson, 1936).

\section{Discussion}

The nesting and foraging habits of most termites should protect colonies from excesses of air, soil, or substrate temperatures found at elevational or latitudinal extremes. However, only two genera, Zootermopsis and Reticulitermes, live in climates where the mean annual temperatures ranges between $4-6^{\circ} \mathrm{C}$, while Porotermes quadricollis and Stolotermes ruficeps occur at $8^{\circ} \mathrm{C}$ (Puerto Aisen, Chile) and $10^{\circ} \mathrm{C}$ (Intercargil, New Zealand) respectively. Cabrera and Kamble (2001) showed that Reticulitermes flavipes foragers avoid the coldest periods by harboring in warmer soil refugia. Cook and Smith (1942) reported that the metabolism of the protist symbionts of Zootermopsis were similar at $9^{\circ}$ to $29^{\circ} \mathrm{C}$, but stopped at $4^{\circ} \mathrm{C}$ leading to starvation of the termites. Lacey et al. (2010) have recently shown that trehalose is used as a cryoprotectant in both Porotermes and Stolotermes in Australian climates which are much warmer than those of either southern Chile or New
Zealand. It is unclear why termites, especially Reticulitermes, do not reside naturally in northern Europe or the British Isles (Harris, 1962) where mean/minimum temperatures (e.g. Warsaw, Poland, $8^{\circ} /-30^{\circ} \mathrm{C}$; Edinburgh, Scotland, $9^{\circ} /-17^{\circ} \mathrm{C}$; and London, England, $10^{\circ} / 13^{\circ} \mathrm{C}$ ) are above the temperatures where Reticulitermes and Zootermopsis occur in the northern United States and Canada.

Termites appear to inhabit all geographic regions with high thermal maxima or mean temperatures as long as food and ground moisture are sufficiently available. The overwhelming majority of termites live in humid tropical environments (Jones \& Eggleton, 2011). In seasonally hot regions termites move into cooler, deeper soils to avoid periods of excessive maximum surface temperatures (Heterotermes aureus and Gnathamitermes perplexus, Collins et al., 1973) or into cooler deeper or lower wood substrata (Incisitermes fruticavus Rust, Rust et al., 1979). Paraneotermes simplicicornisis the only example of a kalotermitid that has adapted to hot seasonal climates by evolving a completely subterranean habit (Light, 1937).

Regarding elevation (e.g., Cr. brevis in Bogota Colombia, $2600 \mathrm{~m}$ ), anthropogenic introductions of exotic termites within buildings often exceed latitudinal limits. For example, a $\mathrm{Na}$. corniger colony was observed building foraging tubes from a potted plant near the swimming pool of a fitness club in East Kilbride, Scotland $\left(57.213^{\circ} \mathrm{N}, 5.997^{\circ} \mathrm{W}\right.$, Scheffrahn et al., 2002). The plant had been imported from Barbados. Cryptotermes brevis was collected in Anchorage, Alaska $(61.21 \mathrm{~N},-149.89 \mathrm{~W})$, from a bookcase originally transported from Hawaii (Scheffrahn unpubl. data).

Worldwide, Z. angusticollis shows the greatest adaptation of any termite to climatic and geographic variability. This species occupies a $93^{\circ} \mathrm{C}$ temperature range from New Meadows, Idaho $\left(-45^{\circ} \mathrm{Cmin}\right.$. record) to Riverside, California $\left(48^{\circ} \mathrm{C}\right.$ max. record). In addition, the vast elevational range of Z. angusticollis from $2124 \mathrm{~m}$ in the Sierra Nevada mountains of California (Weesner, 1965) to sea level (Los Angeles, Banks and Snyder 1920; Santa Monica CA, Scheffrahn unpublished), a large precipitation range (197 cm Tatoosh Island, Washington State, Thorne et al., 1993) to Riverside, CA, $(26 \mathrm{~cm})$ and a vast geographical range extending 3,000 km from Guadeloupe Is., Mexico (Light, 1933), to Prince Rupert, B.C., attest to the remarkable climatic tolerance of this species.

\section{Taxonomic Summary}

Rugitermes laticollis Snyder 1957

\section{DESCRIPTION}

Imago (modified from Snyder, 1957, Figs 2, 4; Appendix). Head capsule very dark brown to black except for dark ferruginous border around antennal sockets. Dorsum of body, including pronotum, concolorous with head capsule. Postclypeus yellowish, labrum light brown. Compound eyes 


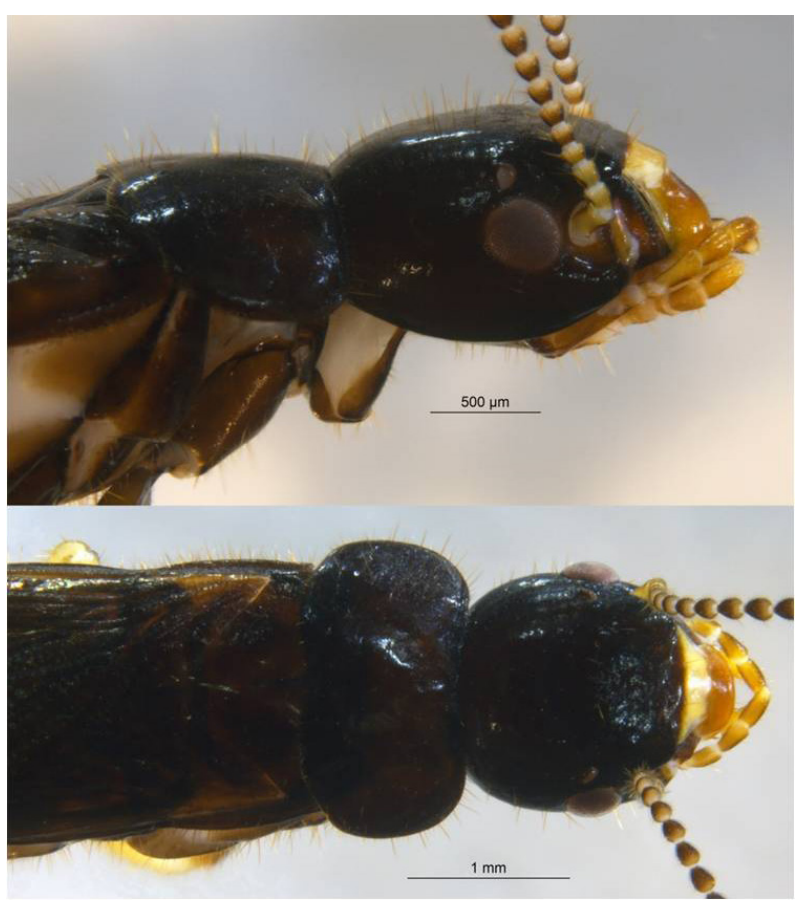

Fig 2. Rugitermes laticollis.Oblique lateral and dorsal views of the imago head and pronotum.

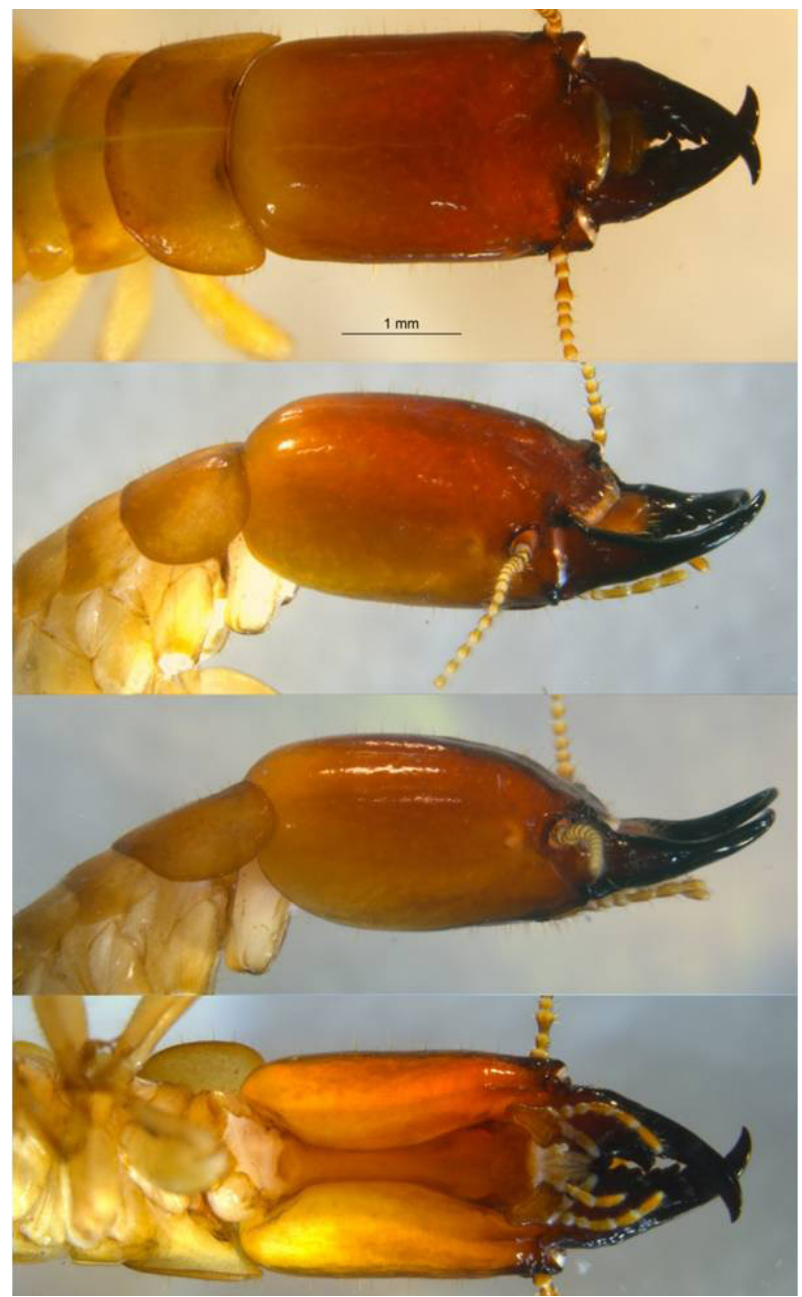

Fig 3. Rugitermes laticollis.Dorsal, oblique, lateral, and ventral views of the soldier head and pronotum. and ocelli very dark gray; compound eyes small; occupying mid one-third of lateral head capsule aspect. Pronotum wider than head capsule. Antennae with 15 articles; basal articles concolorous with labrum, becoming darker toward apex. Head, pronotum, and wing scale generously covered with both long and short setae. Setae widely dispersed on abdominal tergites, and sternites. Pronotum with scattered long and short setae; anterior margin weakly concave, posterior emarginate in middle. Compound eyes subcircular; eye margins broadly subrectate along antennal sockets. Ocelli hyaline, slightly protruding, suboval; well separated from eyes. Wing membrane smoky brown with bronze and greenish prismatic sheen in live specimens (Fig 4); membrane covered with tiny punctuations; sclerotized veins dark brown. Venation as in Fig 13 of Krishna (1961). In forewing, all major veins emerge from scale independently; sclerotized median vein joins radial sector about one-eight distance to wing tip; cubitus unsclerotized and running parallel with radial sector to tip of wing. Hind wing without median vein. Arolia present.

Comparisons. Unlike many species of Rugitermes that are bicolored (usually pronotum and/or wings contrast with head coloration), the imago of $R$. laticollis is evenly and very darkly concolorous. The imago of Rugitermes niger Oliveira 1979 is also uniformly very dark (dark brown to black) but it is much smaller (head width 1.26-1.34 mm).

Soldier (Figs 3, 4; Table 2). Monomorphic. Head capsule rectangular; lateral margins parallel in dorsal view. Antenna with 14 articles $2<3>4=5$; third article clavate and twice the length of second. Mandibles orange-brown near base, grading to castaneus before first marginal tooth and black to apical tooth. Pronotum pale yellow at posterior margin grading to reddish orange from anterior fourth to anterolateral margins. Mandibles project about one-half length of head capsule; without basal hump. Anterolateral corners of genae prominent; forming angular corners when viewed from above. Antennal ridge robust over antennal sockets but gives way to weakly rugose concavity formed by frons. Head capsule slightly wider than pronotum.Pronotum collar-like; anterior margin evenly concave; posterior margin evenly convex with small concavity in middle. Gula slender in middle, about one-third width of anterior portion.

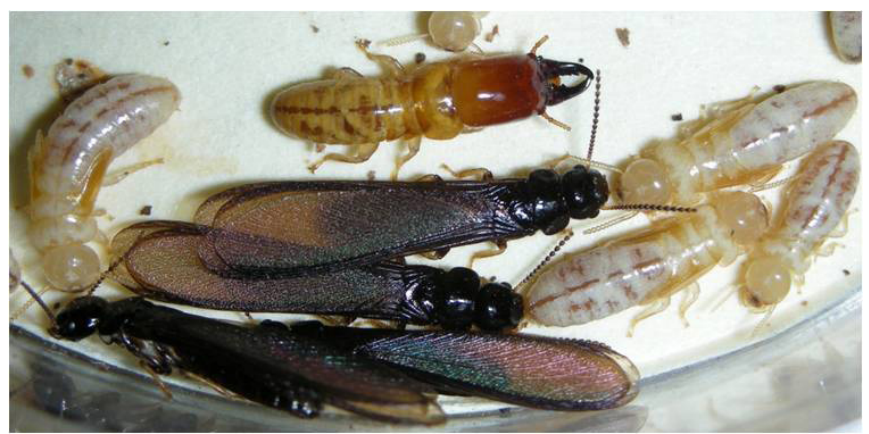

Fig 4. Habitus of a soldier, imagoes, and nymphs of Rugitermes laticollis. 
Comparisons. Soldiers of $R u$. laticollis cannot be confidently separated from congeners using the soldier caste alone, however, for those species with uniformly dark imagoes, the soldiers of Ru. laticollis are the largest.

Material Examined. Bolivia, Depto. de La Paz: Luribay (-17.05994 lat., -67.66363 long.; elev ca. 3600 m), DEC 1986, col. R. Subieta, UF collection no. SA1, (2 soldiers and pseudergates; ex. live branch of peach (Prunus) tree). Ecuador, Distr. Pichincha: Quito, Parque La Carolina, (-0.18845, -78.48595; elev $2780 \mathrm{~m}), 3$ JUN 2011, col. A Mullins, EC1465 (alates, soldiers, nymphs; ex. dead portion of live tree, Fig 5).Adjacent Quito locality (-0.18879, -78.48556) 4 JUN 2011, col. Krecek, Mullins, Scheffrahn; EC1466 (alates, soldiers, nymphs), ex. dead portion of live tree Fig 5).Adjacent Quito locality (-0.18879, -78.48556) 4 JUN 2011, col. Krecek, Mullins, Scheffrahn; EC1467 (soldiers and nymphs), ex. dead portion of live tree.

Biology. Rugitermes laticollis colonizes live or dead wood occasionally exposed to freezing temperatures in the upper montane zone of Andes (2300 to $3630 \mathrm{~m}$ as defined by Young \& Keating, 2001). Alates in Quito were found in June but the timing of flight season is uncertain. The dark coloration suggests daytime flight which may improve alate mobility compared to cool nighttime mountain temperatures. Although known from only three locations, $R u$. laticollismay well occur over a large area of Andean highlands which support woody growth.

\section{Acknowledgements}

We thank Tiago F. Carrijo, John Warner, and Ben Gillenwaters for their reviews. Termites collected under permit no. 06-2011-FAU-DPAP-MA, Ministerio del Ambiente, Quito Ecuador.

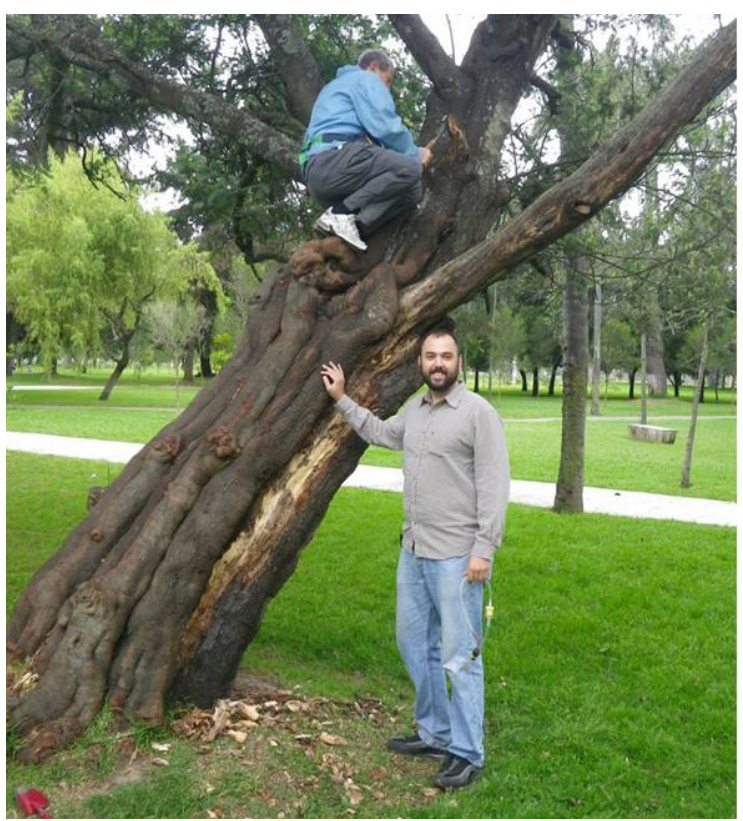

Fig 5. Collection site of Rugitermes laticollis in Quito, Ecuador.

\section{References}

Atkin, L., \& Proctor, J. (1988).Invertebrates in the litter and soil on Volcan Barva, Costa Rica. Journal of Tropical Ecology, 4: 307-310.

Austin, J.W., Szalanski, A.L., Uva, P., Bagnères, A.G. \& Kence, A. (2002). A comparative genetic analysis of the subterranean termite genus Reticulitermes (Isoptera: Rhinotermitidae). Annals of the Entomological Society of America, 95: 753-760.

Bain, J. \& Jenkin, M.J. (1983).Kalotermes banksiae, Glyptotermes brevicornis, and other termites (Isoptera) in New Zealand. New Zealand Entomologist, 7: 365-371.

Banks, N., \& T.E. Snyder.(1920). A revision of the Nearctic termites, with notes on the biology and distribution of termites. United States National Museum Bulletin, 108: [i]viii $+1-228+35$ pls.

Bourguignon, T., Leponce, M., \& Roisin, Y. (2008). Revision of the Termitinae with snapping soldiers (Isoptera: Termitidae) from New Guinea. Zootaxa, 1769: 1-34

Cabrera, B. J., \& Kamble, S.T. (2001). Effects of decreasing thermophotoperiod on the eastern subterranean termite (Isoptera: Rhinotermitidae). Environmental Entomology, 30: 166-171.

Cancello, E.M., Silva, R. R., Vasconcellos, A., Reis, Y.T., \& Oliveira, L.M. (2014).Latitudinal variation in termite species richness and abundance along the Brazilian Atlantic Forest hotspot. Biotropica, 46, 441-450.

Collins, N.M. (1980).The distribution of soil macrofauna on the west ridge of Gunung (Mount) Mulu, Sarawak. Oecologia, 44: 263-275.

Collins, M. S., Haverty, M. I., La Fage, J. P., \& Nuiting, W. L. (1973).High-temperature tolterance in two species of subterranean termites from the Sonoran Desert in Arizona. Environmental Entomology, 2: 1122-1123.

Cook, S. F., \& Smith, R. E. (1942). Metabolic relations in the termite-protozoa symbiosis: Temperature effects. Journal of Cellular and Comparative Physiology, 19: 211-219.

Constantino, R. (1998). Catalog of the living termites of the New World (Insecta: Isoptera). Arquivos de Zoologia, 35: 135-230.

Constantino, R., Liotta J., \& Giacosa B. (2002).A reexamination of the systematic position of Amitermes brevicorniger, with the description of a new genus (Isoptera, Termitidae, Termitinae). Sociobiology, 39: 453-463.

Cowie, R.H, Wood, T.G., Barnett, E.A, Sands W.A., \& Black, H.I.J. (1990).Checklist of the termites of Ethiopia with a review of their biology, distribution, and pest status. African Journal of Ecology, 28: 21-31. 
Darlington, J.P.E.C. (1985). Lenticular soil mounds in the Kenya highlands. Oecologia, 66: 116-121.

Debelo, D. G., \& Degaga, E. G. (2014). Termite species composition in the central rift valley of Ethiopia. Agriculture and Biology Journal of North America 5: 123-134

Donovan S.E., Eggleton, P., \& Martin A. (2002). Species composition of termites of the Nyika plateau forests, northern Malawi, over an altitudinal gradient. African Journal of Ecology, 40: 379-385.

Eggleton, P. (2000). Global patterns of termite diversity. pp. 25-52 in T. Abe, M. Higashi, D.E. Bignell (Eds.), Termites: Evolution, Sociality, Symbioses, Ecology, Kluwer Academic, Dordrecht.

Emerson, A. E. (1936). Distribution of termites. Science, 83: (2157), 410.

Emerson, A. E. (1952).The biogeography of termites. Bulletin of the American Museum of Natural History, 99: 217-225.

Emerson, A.E. (1955). Geographical origins and dispersions of termite genera. Fieldiana: Zoology, 37: 465-521.

Gathorne-Hardy, F., Syaukani, \& Eggleton, P. (2001).The effects of altitude and rainfall on the composition of the termites (Isoptera) of the Leuser Ecosystem (Sumatra, Indonesia). Journal of Tropical Ecology, 17: 379-393.

Harris, V. (1962).Termites in Europe. New Scientist,13: 614-617.

Harris, W. V. (1964). A new species of Angulitermes from Israel (Isoptera, Termitidae). Journal of Natural History, 7(75): 171-172.

Harris, W.V. (1966). Isoptera from Libya. Studi Sassaresi, Sexione III, Annali della Facoltà di Agraria dell'Università di Sassari, 14: 3-8.

Imms, A.D. (1920). On the structure and biology of Archotermopsis, together with descriptions of new species of intestinal protozoa, and general observations on the Isoptera. Philosophical Transactions of the Royal Society of London. Series B, Containing Papers of a Biological Character, 75-180.

Inoue, T., Takematsu,Y., Yamada, A., Hongoh, Y., Johjima, T., Moriya, S., Sornnuwat, Y., Vongkaluang, C., Ohkuma, M., \& Kudo, T. (2006). Diversity and abundance of termites along an altitudinal gradient in Khao Kitchagoot National Park, Thailand. Journal of Tropical Ecology, 22: 609-612.

Jones, D. T., \& Eggleton, P. (2011). Global biogeography of termites: a compilation of sources. In Biology of termites: a modern synthesis (pp. 477-498). Springer Netherlands.

Kooyman, C., \& Onck, R.F M. (1987).Distribution of termite (Isoptera) species in southwestern Kenya in relation to land use and the morphology of their galleries. Biology and Fertility of Soils, 3: 69-73.
Krishna, K. (1961).A generic revision and phylogenetic study of the family Kalotermitidae (Isoptera). Bulletin of the American Museum of Natural History, 122: 303-408.

Len, T., \& Proctor, J. (1997).Invertebrates in the litter and soil on the ultramafic Mount Giting-Giting, Philippines. Journal of Tropical Ecology, 13: 125-131.

Lacey, M.J., Lenz, M., \& Evans, T.A. (2010).Cryoprotection in dampwood termites (Termopsidae, Isoptera). Journal of Insect Physiology, 56: 1-7.

Light, S.F. (1933).Termites of western Mexico. University of California Press, 6: 79-152+ plates.

Light, S.F. (1937). Contributions to the biology and taxonomy of Kalotermes (Paraneotermes) simplicicornis Banks (Isoptera). University of California Publications in Entomology, 6:423-464.

Mittelbach, G. G., Schemske, D. W., Cornell, H. V., Allen, A. P., Brown, J. M., Bush, M. B., ... \& Turelli, M. (2007). Evolution and the latitudinal diversity gradient: speciation, extinction and biogeography. Ecology Letters, 10: 315-331.

Mori, M., Yoshimura, T., \& Takematsu, Y. (2002).Termite inhabitation in northern Hokkaido (in Japanese). Shiroari, 127: 12-19.

Oliveira, G.M.F. (1979).Rugitermes niger (Isoptera, Kalotermitidae), nova espécie de térmita do sul do Brasil. Dusenia, 11: 9-14.

Palin, O.F., Eggleton, P., Malhi, Y.C., Girardin, A.J., RozasDa'vila, A. \& Parr, C.L. (2011). Termite diversity along an Amazon-Andes elevation gradient, Peru. Biotropica, 43: 100107.

Rahbek, C. (1995). The elevational gradient of species richness: a uniform pattern? Ecography, 18: 200-205.

Roonwal, M. L., Bose, G., \& Verma, S. C. (1984).The Himalayan termite, Archotermopsis wroughtoni (synonyms radcliffei and deodarae).Identity, distribution and biology. Records of the Zoological Survey of India, 81: 315-38.

Roonwal, M.L., \& Chhotani, O.B. (1989.)The fauna of India and adjacent countries.Isoptera (termites).Vol. 1. Calcutta: Zoological Survey of India, [8] + viii +672 pp.

Ruelle, J.E. (1970). A revision of the termites of the genus Macrotermes from the Ethiopian region (Isoptera: Termitidae). Bulletin of the British Museum (Natural History), Entomology, 24: 363-444.

Rust, M.K., Reierson, D.A., \& Scheffrahn, R.H. (1979). Comparative habits, host utilizationand xeric adaptations of the southwestern drywood termites, Incisitermes fruticavus Rustand Incisitermes minor (Hagen). Sociobiology, 4: 239-255.

Scheffrahn, R. H. (2014). Incisitermes nishimurai, a new drywood termite species (Isoptera: Kalotermitidae) from the 
highlands of Central America. Zootaxa, 3878(5), 471-478.

Scheffrahn, R. H., Cabrera, B. J., Kern Jr, W. H., \& Su, N. Y. (2002). Nasutitermes costalis (Isoptera: Termitidae) in Florida: first record of a non-endemic establishment by a higher termite. Florida Entomologist, 85: 273-275.

Scheffrahn, R. H., \& Huchet, J. B. (2010). A new termite species (Isoptera: Termitidae: Termitinae: Amitermes) and first record of a subterranean termite from the coastal desert of South America. Zootaxa, 2328,:65-68.

Scheffrahn, R.H., Křeček, J., Ripa, R., \& Luppichini, P. (2009). Endemic origin and vast anthropogenic dispersal of the West Indian drywood termite. Biological Invasions, 11: 787-799.

Sjöstedt, Y. (1905). Über eine Termitensammlung aus Kongo und anderen Teilen von Afrika. Arkiv för Zoologi, 2: 1-20.

Snyder, T.E.(1926). Termites collected on the Mulford Biological Exploration to the Amazon Basin, 1921-1922. Proceedings of the United States National Museum 68: 1-76 + 3 pls.

Snyder, T.E. (1957).A new Rugitermes from Bolivia (Isoptera, Kalotermitidae).Proceedings of the Entomological Society of Washington, 59: 81-82.

Spaeth, V. A. (1964). Three New Species of Termites from Israel (Termitidae Amitermitinae). Israel Journal of Zoology, 13(1), 27-33.

Thakur, M.L. (1981). The identity, distribution and bioecology ofOdontotermes distans Holmgren et Holmgren (Isoptera: Termitidae: Macrotermitinae). Proceedings: Animal Sciences, 90: 187-193.

Thorne, B.L., Haverty, M.I., Page, M., \& Nutting, W.L. (1993). Distribution and biogeography of the North American termite genus Zootermopsis (Isoptera: Termopsidae). Annals of the Entomological Society of America, 86: 532-544.
Thomas, L. \& Proctor, J. (1997).Invertebrates in the litter and soil on the ultramafic Mount Giting-Giting, Philippines. Journal of Tropical Ecology. 13: 125-131.

Udvardy, M.D.F. (1975). A classification of the biogeographical provinces of the world.Occasional paper 18. World Conservation Union, Morges, Switzerland.

Vickery, V.R., \& Kevan, D.K.M. (1985). The insects and arachnids of Canada, part 14. The grasshoppers, crickets and related insects of Canada and adjacent regions. Ulonata: Dermaptera, Cheleutoptera, Notoptera, Dictyoptera, Grylloptera, and Orthoptera. Agriculture Canada Research Branch Publication 1777, Ottawa, Ontario.

Weesner, F.M. (1965). Termites of the United States: a handbook. National Pest Control Association, Elizabeth, New Jersey, $70 \mathrm{pp}$.

Weidner, H. (1960). Die Termiten von Afghanistan, Iran und Irak (Isoptera). Sonderdruck aus Abhandlungen aund Verhandlungen des Naturvissenschaftlichen Verieins in Hambure, N. F. 4: 43-70.

Williams, R.M.C. (1966). The East African termites of the genus Cubitermes (Isoptera: Termitidae). Transactions of the Royal Entomological Society of London, 118: 73-118.

Willig, M.R., Kaufman, D.M., \& Stevens, R.D. (2003). Latitudinal gradients of biodiversity: pattern, process, scale, and synthesis. Annual Review of Ecology, Evolution and Systematics, 34: 273-309.

Young, K. R., \& Keating, P. L. (2001).Remnant forests of Volcán Cotacachi, northern Ecuador. Arctic, Antarctic and Alpine Research, 165-172. 


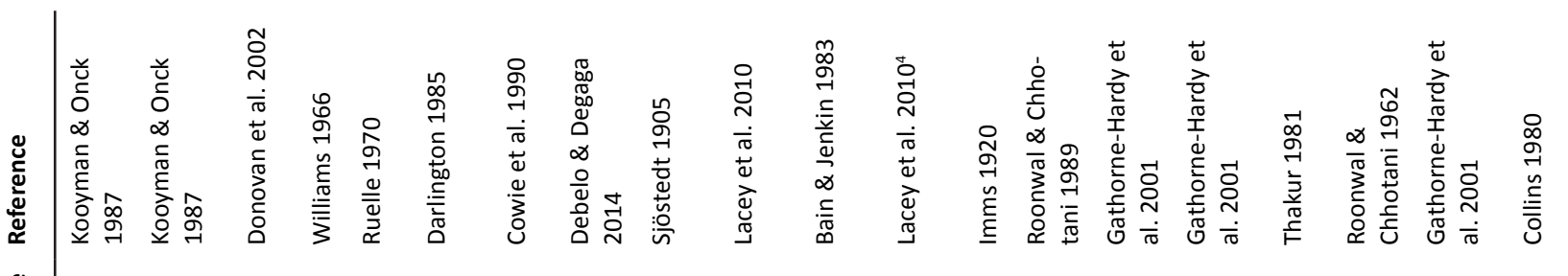

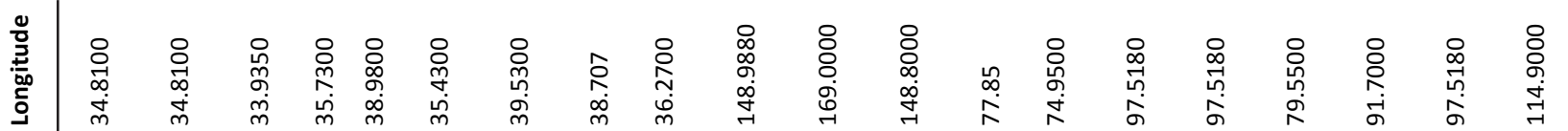

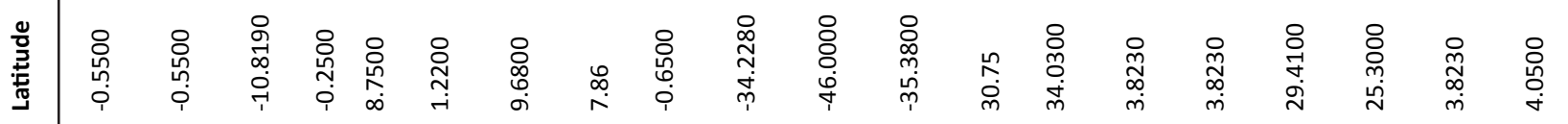

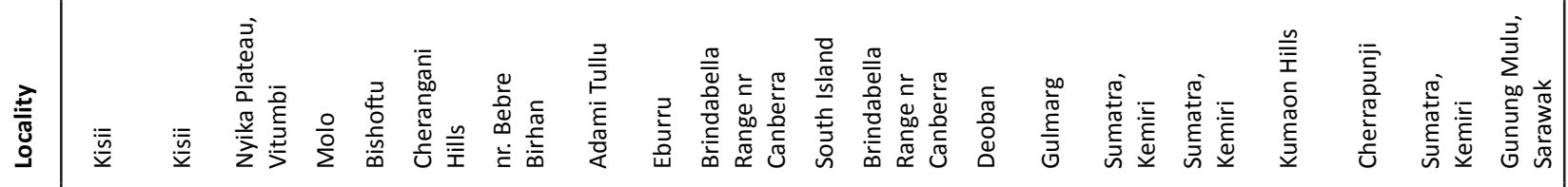

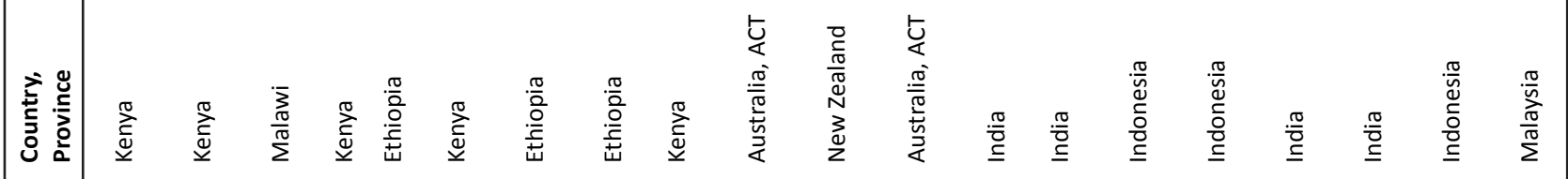
芯

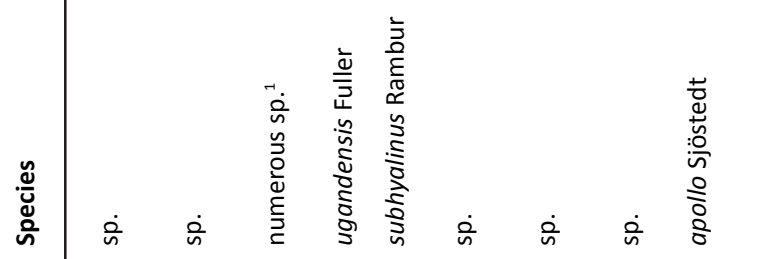

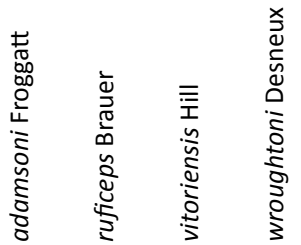

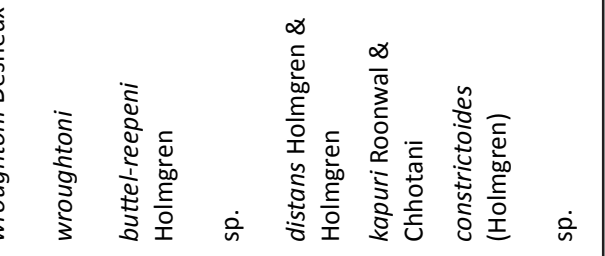




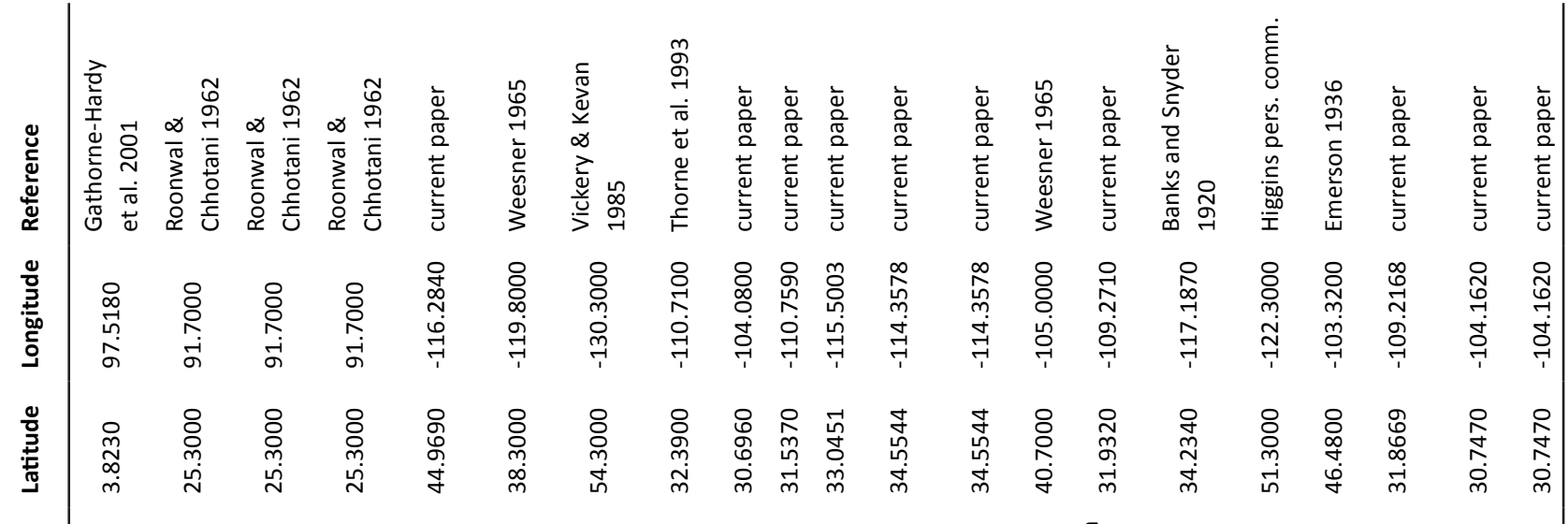

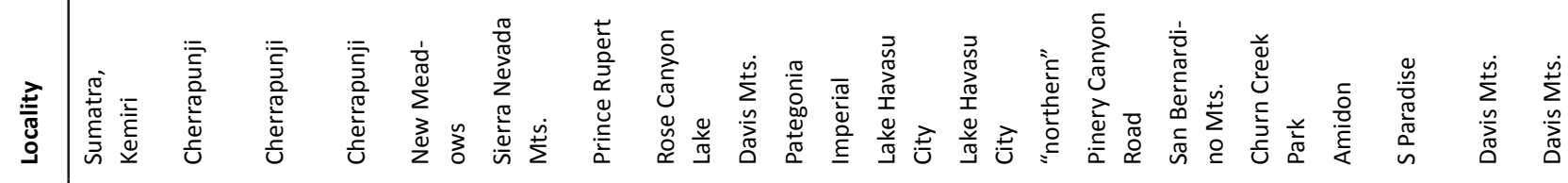

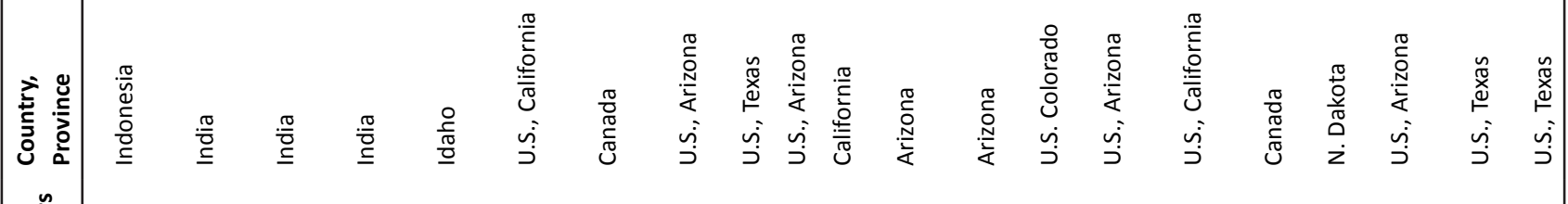

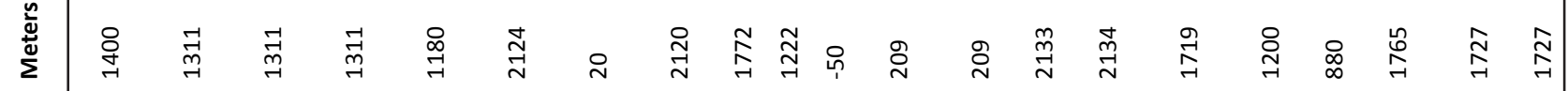

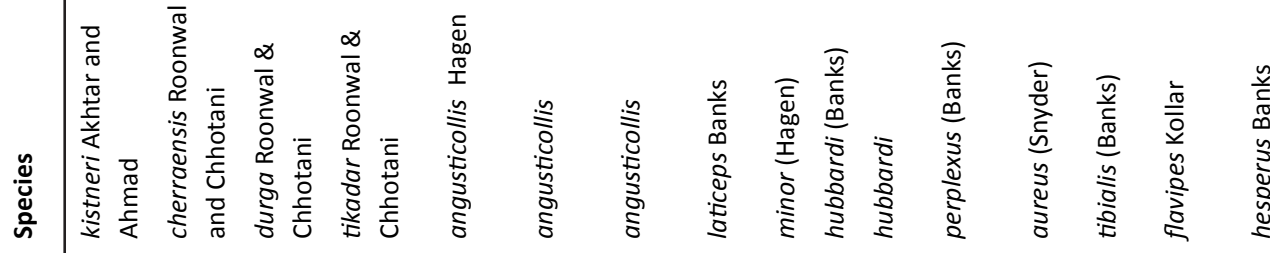

(1)

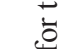

\section{要}

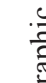

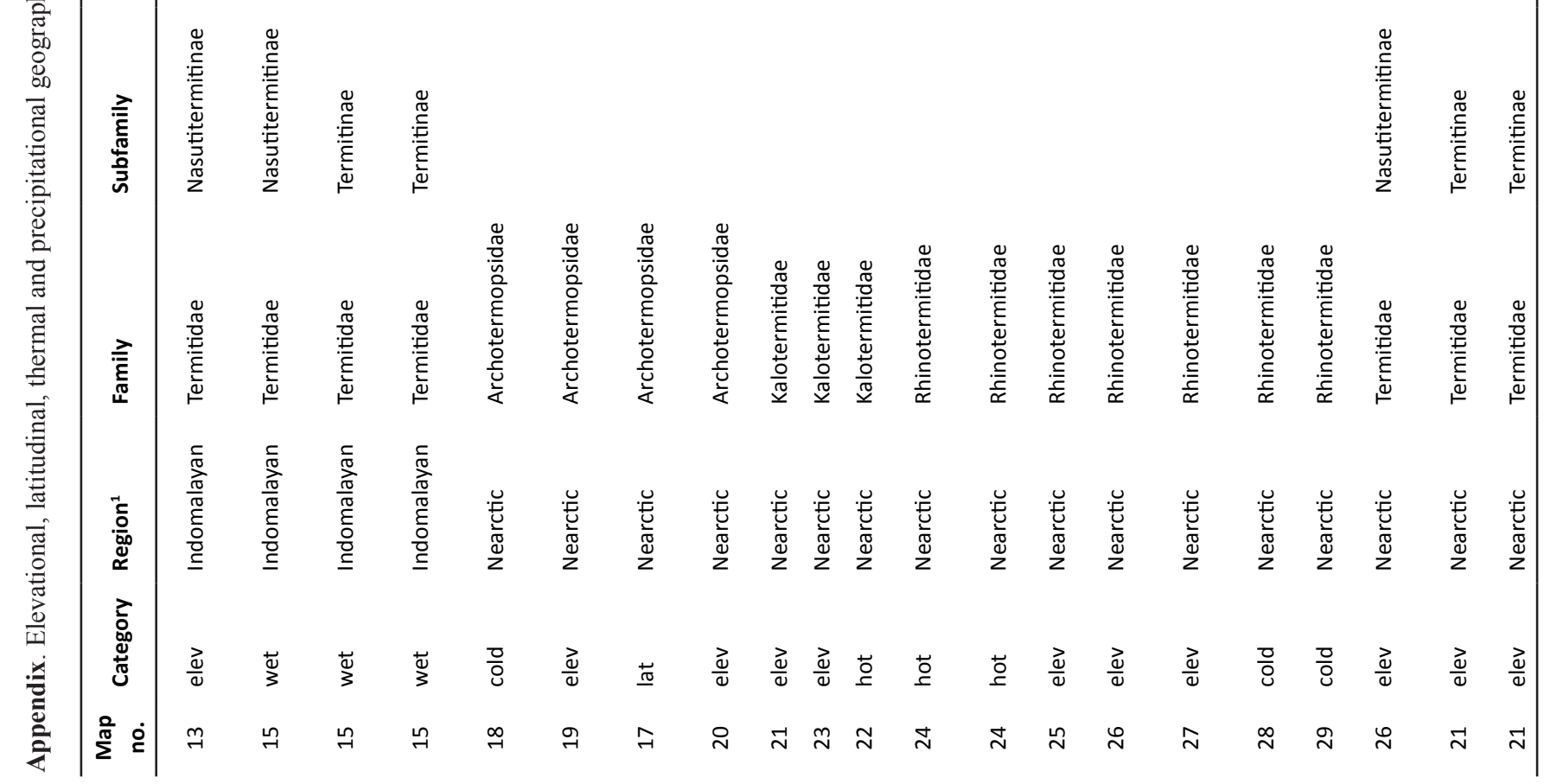




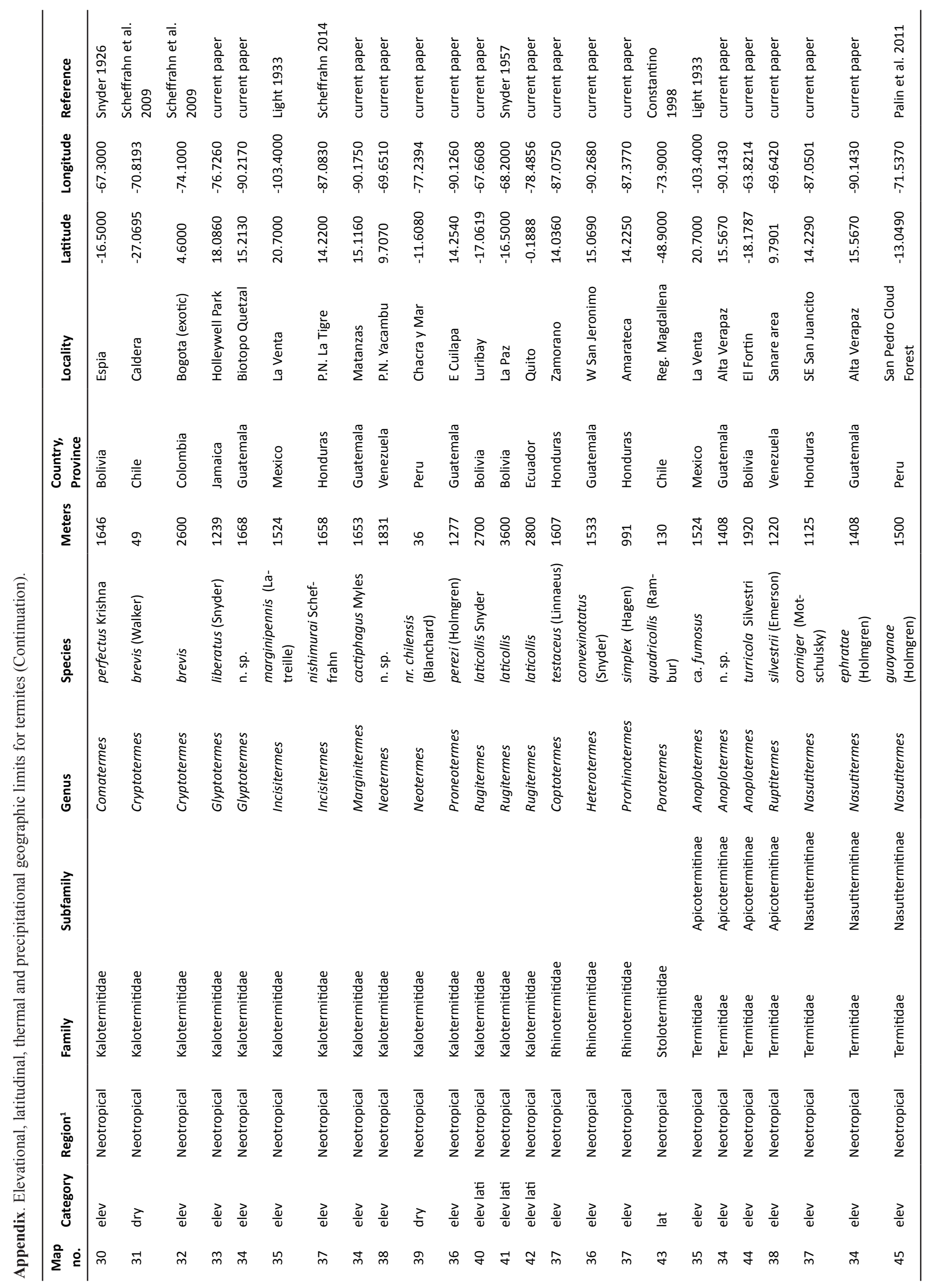




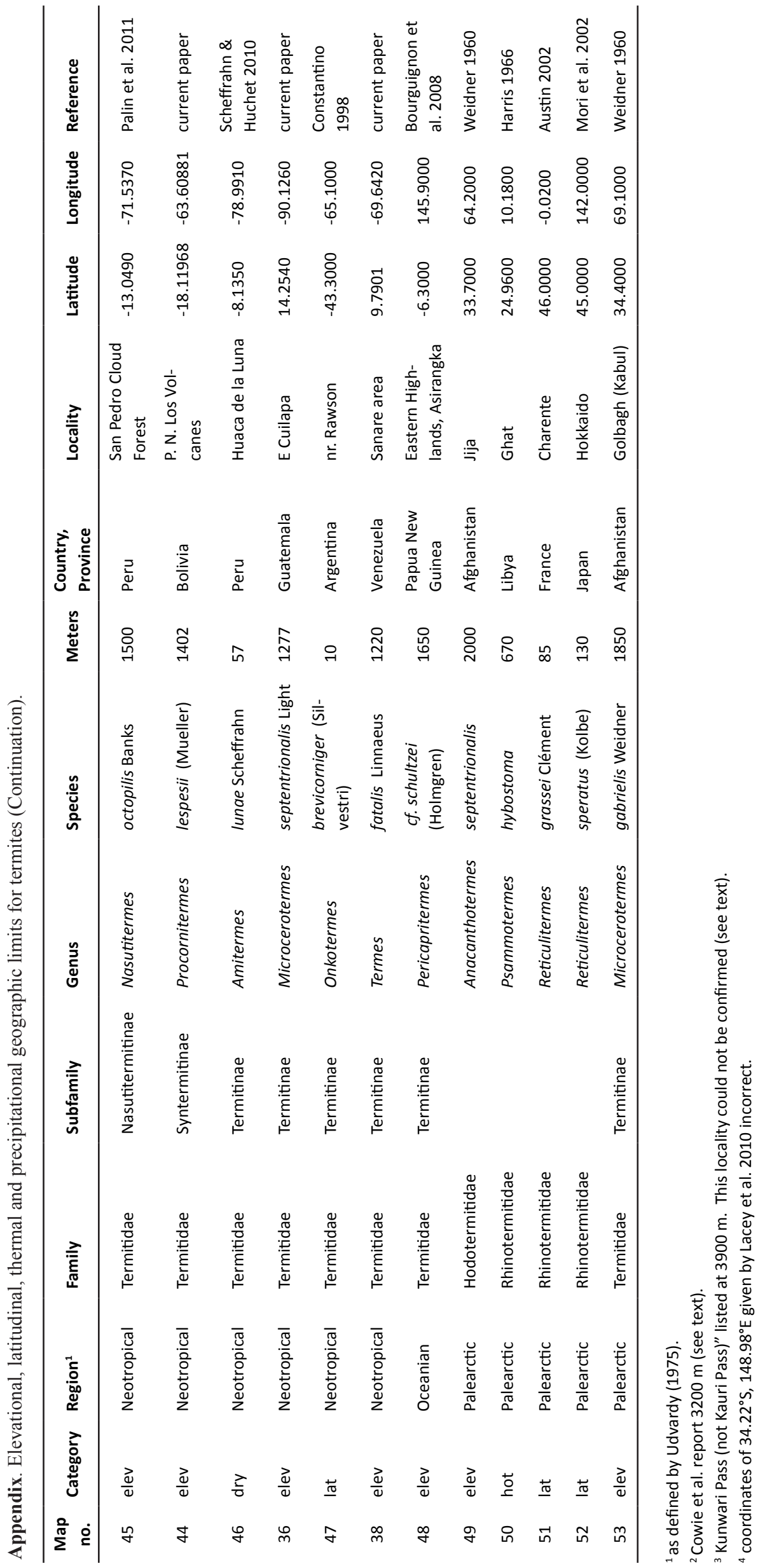

